\title{
UNIKÁTNÍ SOUČÁST ZBROJE Z HRADU RONOVCE (OKRES HAVLÍČKŮV BROD)
}

\author{
ALEŠ KNÁPEK - PAVEL MACKŮ \\ Abstrakt: Na hradě Ronovci byla v roce 1958 objevena železná součást přilby představující jednoduché \\ hledi ve tvaru odklopného nánosniku. Vzhledem k minimálním informacím o nálezových okolnostech tohoto \\ artefaktu a jedinečnosti mezi publikovanými archeologickými artefakty i militarii ze zbrojnic bylo nutné pro \\ určeni jeho časového a sociálního prostředi přistoupit k analýze ze širšiho úhlu pohledu.
}

Klíčová slova: militarium - 14.-15. století-přilba-nánosník-Ronovec.

\section{A Unique Armour Component from Ronovec Castle (Havlíčkův Brod District)}

\begin{abstract}
An iron part of a helmet was excavated in 1958 at Ronovec Castle. It was a simple visor in the shape of a foldable nose-guard. Due to the lack of information about the context of the item and to its unique position among published archaeological artefacts and militaria from armouries, its chronological and social milieu had to be determined with the use of a broader analysis.
\end{abstract}

Key words: militarium - 14th-15th centuries - helmet-nose-guard-Ronovec.

Ve sbírce archeologických nálezů získaných z hradu Ronovce, uchovávané v obci Dolní Krupá, se nachází tvarovaný kovový předmět, jehož význam a účel doposud unikal zájmu badatelů (viz Knápek 2012; 2014). Jde o součást středověkého ochranného odění, přesněji o ranou formu odklopného hledí - nánosníku (Klappvisier, Klappvisor apod.) používanou převážně ve 14. století, v dosud publikovaném archeologickém nálezovém fondu český, potažmo evropský unikát.

Hrad Ronovec (Sommerburg) vznikl původně zřejmě jako lichtenburské založení (Durdík 1999; Sommer 2013) v území, které tento rod kolonizoval a v němž rozvíjel montánní aktivity na stř́ibronosných žílách. Hrad situovaný v nevýrazné poloze na ostrožně nad údolím břevnického potoka leží pouhých 8 kilometrů od centra města Havlíčkova (Smilova, Německého) Brodu (obr. 1). Ve čtrnáctém století se dostal dokonce do královských rukou, a dále pak pánům z Lipé. Od roku 1362 držel hrad zástavou od Čeňka a Jindřicha z Lipé Ješek ze Zlíchova (Tetína), který je zakladatelem rodové linie Andělů z Ronovce. Po něm zůstal hrad v držení jeho synů Jana a Petra z Ronovce, kteř́ jej snad museli opustit v důsledku dědických sporů po smrti Jindřicha z Lipé v roce 1406 (Starý 1999, 32). V patnáctém století se hrad v písemných zprávách již neobjevuje, přestože okolí bylo silně stiženo tehdejšími vojenskými aktivitami jak v období předhusitském, tak v době husitských válek. Pustý je výslovně zmiňován v zemských deskách roku 1544. Zajímavou zmínkou s ne zcela jasným dopadem na problematiku zániku hradu je př́ítomnost jakéhosi Anděla z Krupé (ves $1,4 \mathrm{~km}$ od hradu v původní vazbě) na čáslavském sněmu roku 1440 (šířeji k tomu Rous 2014). Nefunkčnost hradu bychom mohli předpokládat tedy ke zmíněnému datu 1440, kdy již pravděpodobně existovalo sídlo v (Dolní) Krupé na místě dnešního zámku. Potvrzení této skutečnosti máme až z roku 1502, kdy zde seděl Jan Špetle z Prudic.

Nález námi pojednávaného artefaktu byl učiněn v rámci výkopů probíhajících na hradě od roku 1957. Tyto výkopy vedl místní nadšenec Josef Čapek. Nešlo tedy o profesionální aktivitu, ačkoli někteří profesionální badatelé ji sledovali (souhrnně Knápek 2014). Dokumentace výzkumů nám neumožňuje přesně určit místo nálezu. Pravděpodobně pochází z prostoru nádvoří jádra hradu, snad ze zahloubené stavby v blízkosti „studně“ (?), která obsahovala větší množství nálezů ve dvou dokumentovaných horizontech (obr. 2). K nánosníku téměř jistě patří záznam J. Čapka v jeho katalogu (ulož. v D. Krupé), kde je pod číslem 393 uvedeno: „„ćást železného exponátu s křžkem, rok 1958, nalezeno těsně od zdiva hradby na západni straně od studny". Tento zápis dobře odpovídá našim znalostem průběhu prací na hradě (Kronika Dolní Krupé; Čapek 1999). Dodnes dochovaný soubor kovových artefaktů z hradu čítá desítky kusů a jeho menší část byla získána $\mathrm{v} 80$. letech také s pomocí detektoru kovů. Pro zařazení tohoto nánosníku tedy jasné stratigrafické podklady nemáme. 


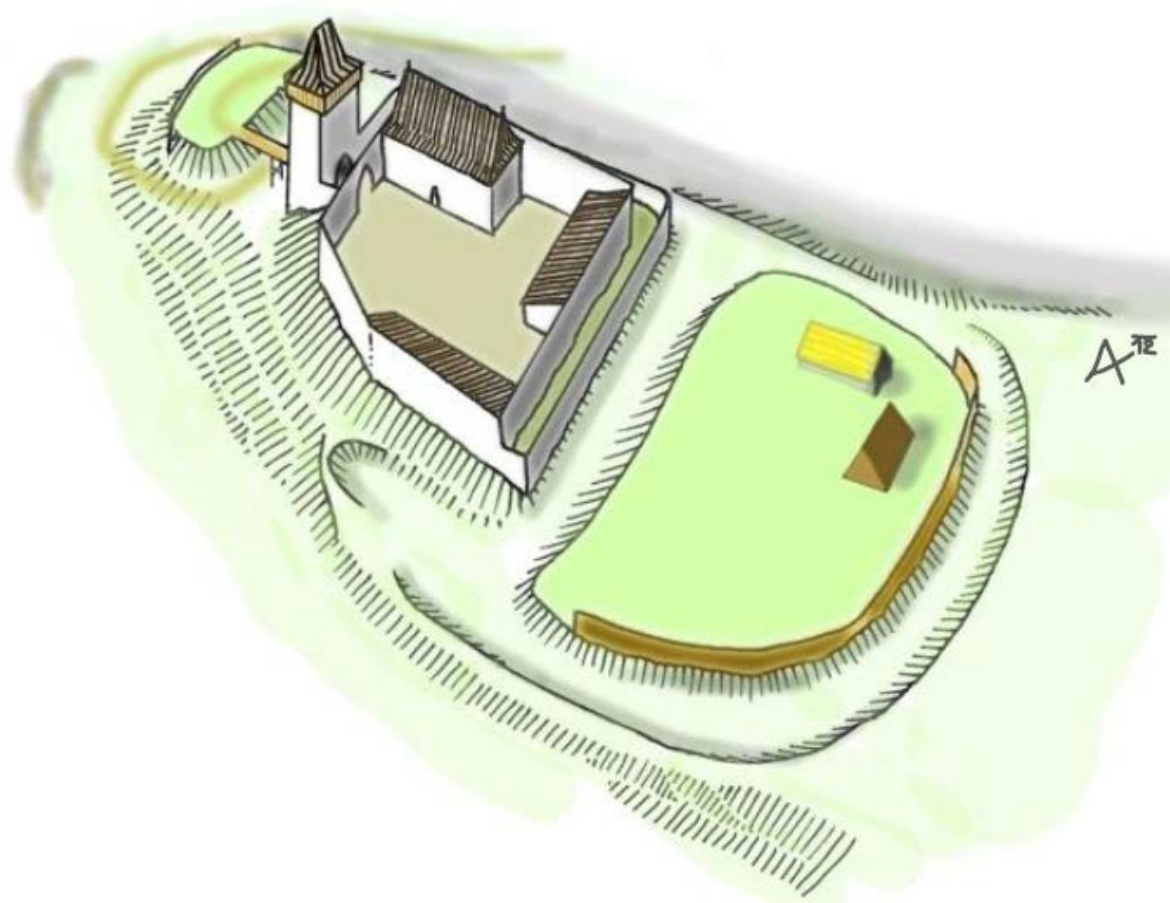

Obr. 1. Axonometrický náčrt hradu Ronovec. Vizualizace A. Knápek.

Abb. 1. Axonometrische Skizze von Burg Ronovec. Visualisierung A. Knápek.

V následujícím textu se pokusíme zasadit tento solitér do kontextu vývoje evropského vojenství a také do dobového sociálního prostředí. Nánosníky jsou reflektovány jak starší odbornou, tak i populární literaturou, která je však většinou jen letmo zmíní či popisuje, ale nezabývá se jejich problematikou do hloubky (např. Boeheim 1890, 34; Funcken-Funcken 2001, 30-31; Glinianowicz 2005; 2010; Głosek 2007; Klučina 2004, 354-359; Le Duc, 2008, 245; Nadolski ed. 1994, 227; Nickel 1974; Nowakowski 1989; 1994, 53; 1997; Vaverková 1991, 381; ad.). Popisovaný nánosník byl již předběžně ve stručnosti publikován (Knápek 2013, 18-20).

Nánosník nalezený na hradě Ronovec je přibližně trojúhelného tvaru, směrem od své základny se zužuje, přičemž zhruba v polovině výšky je po obou stranách výrazně segmentově vykrojen (obr. 3). Skládá se ze tří železných částí. Největší je spodní, nekompletní část, jejíž dochovaný rozměr je $11 \mathrm{~cm}$. Jde o konvexně vyhnutý lopatkovitý tvar se středovou hranou, která v horní části mizí. Toto prohnutí vytváří na středu oproti okraji výškový rozdíl $2,2 \mathrm{~cm}$, čímž je dosaženo zvýšení pevnosti materiálu a jeho odolnosti vůči př́ípadnému zásahu zbraní, a zároveň reflektuje anatomii obličeje, který kryje. Dochovaná síla materiálu se pohybuje od ca 1,5 mm ve spodní části až k $5 \mathrm{~mm}$ v části horní (nutno brát v úvahu korozní činitele). Ta je ukončena dvojicí rozšiřujících se pásků či tyčinek, které jsou přeloženy a svařeny (?). Vytvářejí tak otvor, jímž je protažena železná kulatina. Takto vzniklý pant slouží k přichycení vrchní pohyblivé části nánosníku (obr. 4). Ta je tvořena ze $4-5 \mathrm{~mm}$ silného a $5 \mathrm{~cm}$ vysokého dílu, vykovaného do tvaru protaženého šestiúhelníku, jehož spodní stranu tvoří obdélný výčnělek. Uprostřed je vysekán otvor ve tvaru kříže. V současnosti je pant zarezlý a oba hlavní díly jsou tak ve vzájemné pozici téměř v pravém úhlu. Nánosník je tedy zafixován v „otevřené“ pozici.

Než přistoupíme $\mathrm{k}$ hodnocení popisovaného nánosníku, připomeneme stručně vývojové tendence tohoto typu zbroje. Vývoj militarií ve 14. století byl jedním z nejrychlejších v historii vojenství. Během necelých sta let se př̌šlo od do té doby nejmodernějšího kroužkového kom- 


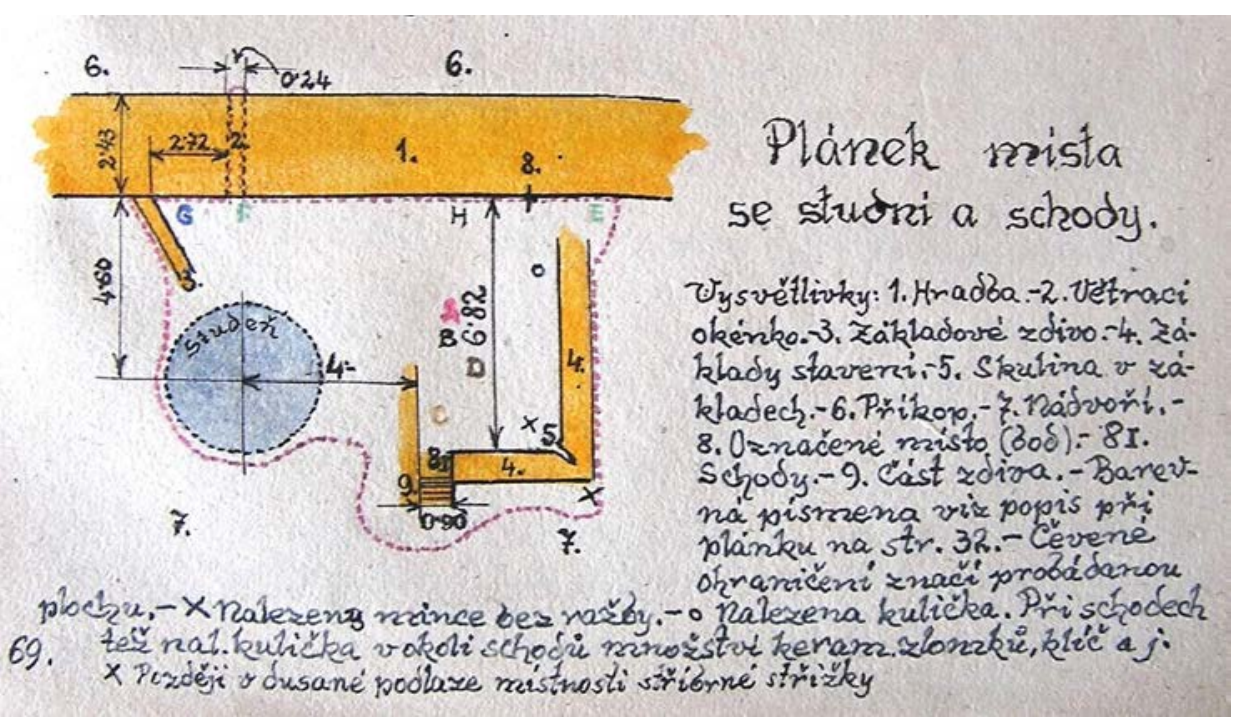

Obr. 2. Situační nákres J. Čapka výkopu poblíž studně.

Abb. 2. Lageplan der von J. Čapek in Brunnennähe gemachten Aushebung.

pletu až po ranou plátovou zbroj. Tato epocha bývá označována jako „doba kombinovaných zbroji““, C. Blair $(1958,55)$ ji označuje jako „dobu experimentu“. Tento přerod totiž probíhal více vývojovými cestami a docházelo $\mathrm{k}$ různým kombinacím kroužkových zbrojí s koženými a plátovými doplňky, které ve finále získaly navrch. Vedlo k tomu mnoho faktorů, např́iklad dokonalejší technologie a možnosti výroby (hamry), ale i nastartovaný proces, kdy vznik nových zbrojí dával podnět k výrobě nových zbraní schopných je překonat a naopak (např. dlouhý meč).

Složitým vývojem v této době prošla také ochrana hlavy, tedy těžké helmice (latinsky helm, galea), ale i lehčí přilbice (výraz „přilbicie“ známe už z Klaretových slovníků, jak to doložili Wagner-Durdík-Drobná 1956, 59). Ze staršího hrncového helmu se vyvinul někdy kolem, či po roce 1300 helm kbelcový (z našeho území jsou publikovány dva exempláře helem, např. v Žákovský 2011, 874-875, obr. 321-322; Žákovský-Hošek-Cisár 2012). Ten byl poněkud větší, se zaobleným vrchlíkem a dosedal svému nositeli téměř nebo zcela na ramena. Vždy pak seděl, oproti helmu hrncovému, na lehčí přilbici (záměrně vynecháváme nečetná vyobrazení z iluminovaných písemných pramenů, kdy jsou jezdci při turnaji po zásahu prostovlasí s odhozeným kbelcovým helmem na zádech). Často byl kbelc jištěn jedním, či spíše dvěma řetězy uchycenými na plátovém kabátci v oblasti prsou (obr. 5:F). Po prvním střetu či v př́ípadě, že ozbrojenec potřeboval lepší výhled, odhodil kbelc na záda, kde byl jištěn zmíněnými řetězy proti ztrátě (k typologii a vývoji helmic zatím nejobsáhleji Pierzak 2004; nejnověji pak Žákovský-Hošek-Cisár 2012; metalografie vybraných kusů např. Wiliams-Edge 2004). Kolem přelomu 14. a 15. století bývaly řetězy již někdy nahrazeny koženými řemeny uchycenými na plátový kabátec či prsní a později i zádový plechový plát zbroje.

Takto shozený kbelc nacházíme $\mathrm{v}$ dobových obrazových i sochařských dílech napříč Evropou. Z přilby snímatelný řetěz byl napevno uchycen na prsních plátech plátového kabátce či brigantiny pomocí do očka vytvarované kulatiny, roznýtované na spodní straně železného plátu zbroje. Toto očko mohlo být na svrchní straně (látce či kůži) plátového kabátce podloženo i kovovou aplikací. Na dochovaných zbrojích nám to dokládá rozeta na jednom exempláři z hradu Küssnach ve Švýcarsku či v aukční síni Hermann Historica nedávno prodaný unikátní plátový kabátec z hradu Hirschstein u Pasova (Gessler 1923; Hermann a kol. 2007; Žákovský 2009, 414-415, obr. 4). Tento z větší části dochovaný plátový kabátec nalezený detektorem obsahoval mj. prsní plát s nýty po obvodu pro uchycení svrchní látkové či kožené vrstvy, ale hlavně se 

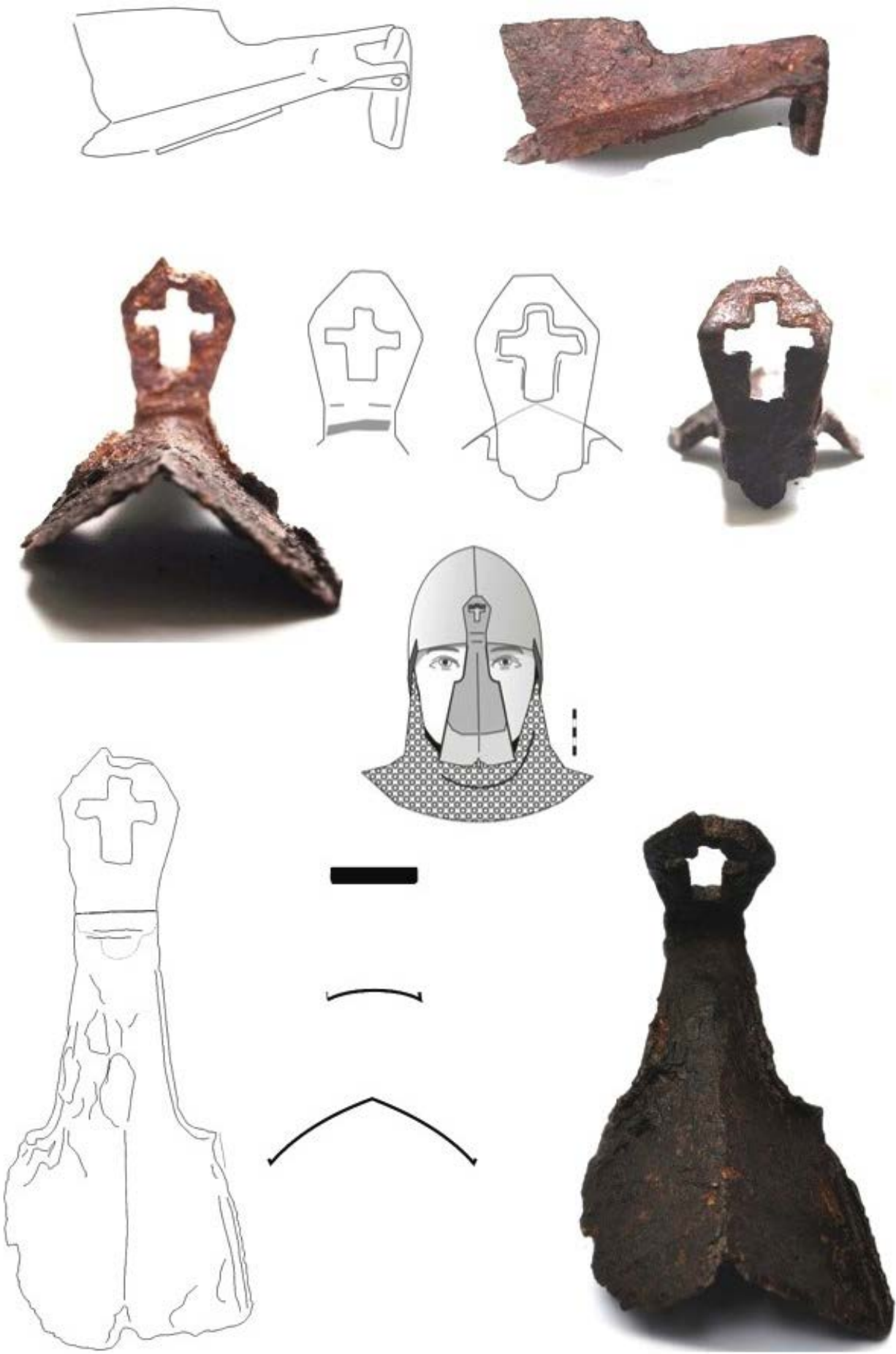

Obr. 3. Nánosník z hradu Ronovce. Kresba a foto A. Knápek, úprava P. Macků.

Abb. 3. Naseneisen von Burg Ronovec. Zeichnungen und Fotos A. Knápek, ergänzt von P. Macků. 


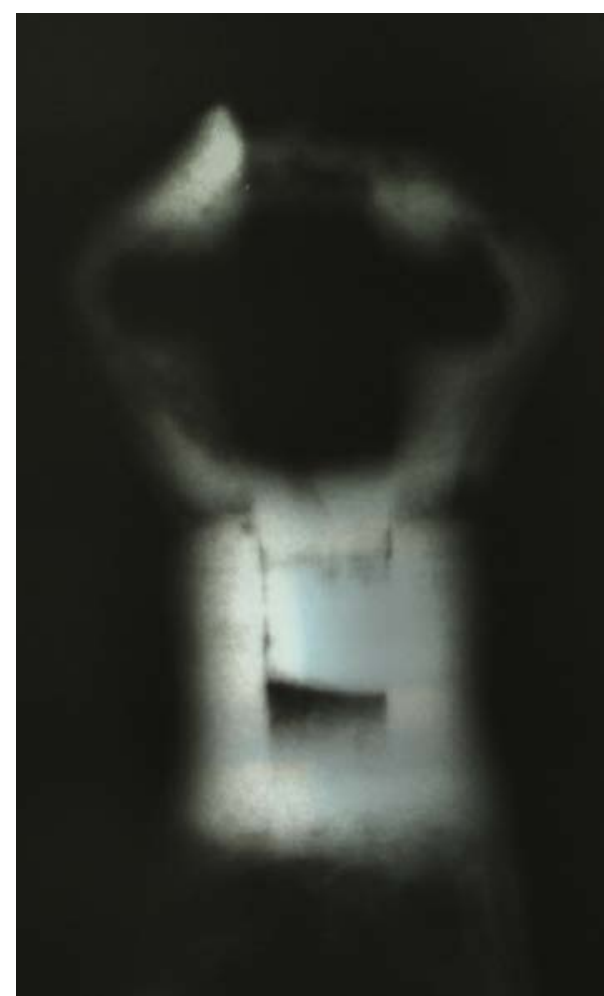

Obr. 4. Rentgenový snímek horní části nánosníku - detail pantu.

Abb. 4. Röntgenaufnahme des oberen Teils des Naseneisen - Detail des Scharniers. čtyřmi úchyty pro řetězy. Očka jsou dochována opět s malými rozetami pod nimi a jsou jimi provlečeny čtyřri více či méně dochované řetězy, z nichž dva mají na posledním článku jakési rozpěrky. Tyto byly prostrčeny otvorem ve spodní části kbelcové helmy, a tím ji zafixovaly před ztrátou. Zbylé dva řetězy pak sloužily $\mathrm{k}$ uchycení meče a dýky proti ztrátě při jízdním boji. $Z$ našeho území máme také dochováno několik exemplářů hrudního plátu $\mathrm{s}$ úpravou pro přichycení řetězu. Jde např. o nálezy z hradu Rychleb ve Slezsku (Goš 1976, 293-296, obr. 2; na tento jev upozornil již Přihoda 1929, 112). Jde o vertikální lamelu z levé části ozbrojencova hrudníku s anatomickým výkrojem pro ruku. Zhruba uprostřed je silně poškozený mosazný fragment, který přesto díky svému umístění a analogiím lze označit jako úchytku na řetěz. Jiný pochází z pravého hrudního plátu brigantiny nalezené v Chocni (?), který nese dva nýty pod výkrojem na ruku (Vích 2009, 15, obr. 29:8). Je však nutné podotknout, že $\mathrm{v}$ tomto př́ípadě mohlo jít i o úchytku pro nedochovanou operrku kopí.

Zmiňme ještě $v$ rámci problematiky řetězů jeden detail. Na vyobrazeních ozbrojenců $\mathrm{v}$ klidu, mimo bojovou aktivitu máme $\mathrm{v}$ obrazových pramenech zachyceno i jejich úplné sejmutí nebo dokonce i zauzlování, čímž se tento jinak nepraktický prvek výrazně zkrátil a svému nositeli nadále nepřekážel (obr. 5).

Původně byla pod kbelcem nošena přilbice zvaná dnes „lebka“ (hawbe, hube, mitra, barbutta, lapka, cervelliere, mitra ferrea atd.) v různých modifikacích slov (obr. 5:E, G), jež byla kulovitého tvaru a kryla vršek hlavy zhruba po úroveň spánků, či lehce přes uši. Z našeho území pochází v roce 1996 objevená lebka datovaná do doby kolem poloviny 14. století z Nymburka (Motyková 2001). Ještě v průběhu první poloviny 14. století dochází k jejímu protažení přes uši a týl hlavy, čímž vznikl tzv. šlap či jinak nazývaný basinet či Beckenhaube (klasická lebka se však také dále udržuje). Jeho tvar prošel od globulárních až po dozadu ubíhající zahrocený vrchlík (morfologii bascinetu řeší už Blair 1958, 51-52). Šlap - v české terminologii - se stal velice populární a nošen byl až hluboko do 15. století (srov. obr. 6-7), kdy definitivně díky své praktičnosti vytlačil těžké helmy pouze na turnajové disciplíny. Z publikovaného nálezového fondu České republiky známe šlap z hradu Lopata či z Kostomlat u Nymburka (viz dále; Frýda 1996, 534, obr. 680; Novobilský 2008, 87, obr. 96; Novotný 1954; Žákovský 2011, 873).

Vzhledem k tomu, že lebka a šlap kryly jen hlavu, byl k těmto přilbám často upevňován kroužkový závěs (Gehenge; v českých pramenech někdy označován též jako obojček, oboječek, obojek; pozor však na záměnu s kroužkovými oboječky nošenými samostatně), který byl uchycen na kožený lem kolem okraje přilby. Tato kožená součást byla nasazena na tzv. vervilles, tedy malá očka či trubičky nanýtované či kovářsky přivařené po okraji přilby. Pro zajištění závěsu pak byla všemi vervilly protažena tkanice zauzlovaná na obou stranách za posledními očky (obr. 5:E, G; 7:H). Grabarczyk-Ławrynowicz (2006, 259-260) uvádí jako další možnost uchycení kroužkového závěsu k přilbě kovovými háčky, ačkoli neuvádějí další podrobnosti. Takovou přilbu, nalezenou v korytě řeky Labe pod hradem Kostomlaty a dnes deponovanou ve Vlasti- 

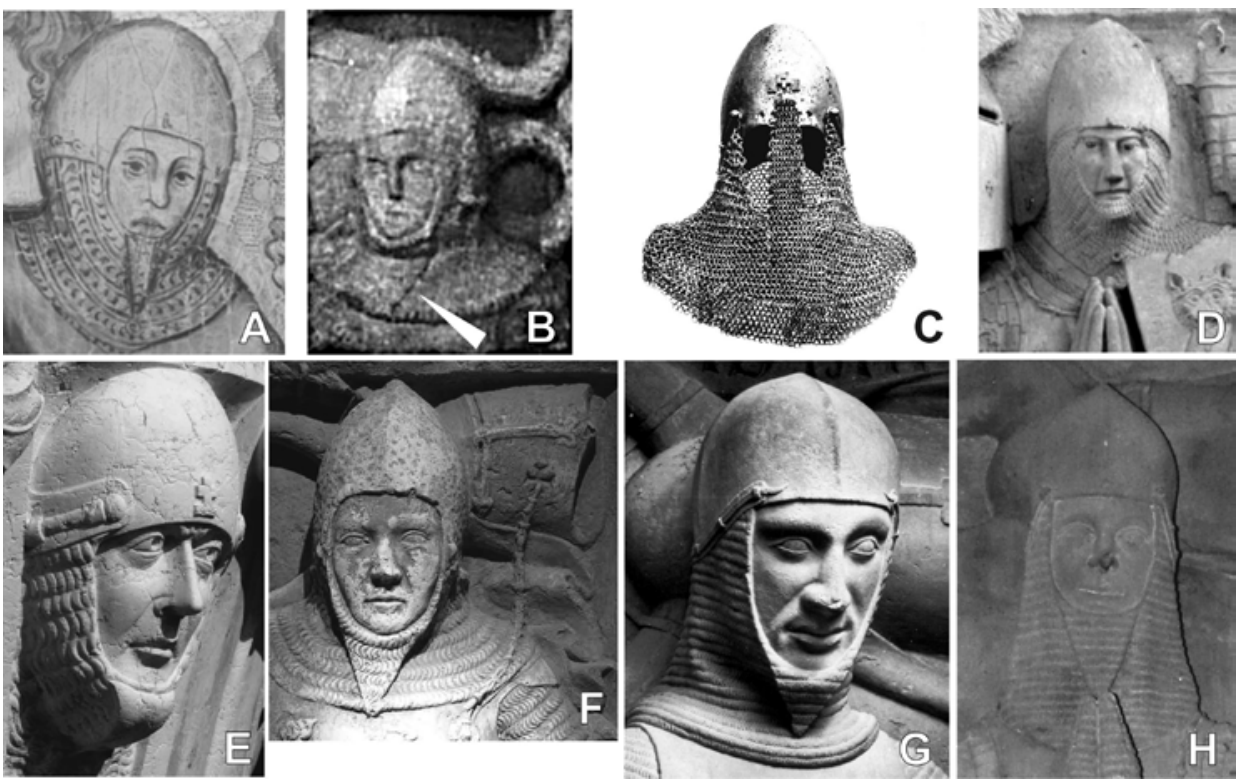

Obr. 5. Starší forma kroužkových nánosníků. A - Pašijový oltář, Jidášova zrada, Klášter Klosterneuburg, Stiftsgalerie, Rakousko, 1335-1340; B - náhrobek Friedricha von Truhendigen († 19. května 1366), kostel sv. Kiliána v Schesslitz, Bavorsko, Německo; C - přilba typu šlap (Beckenhaube) ze sbírek Musea Stibbert ve Florencii, Itálie, okolo roku 1350 - podle Klučina 2004, 351; 2011, 838, obr. 246; D - náhrobek Albrechta von Hohenlohe-Möckühl († 1338), kostel v Schőnthal an der Jagst, Bádensko-Württembersko, Německo - podle Thordeman 1939, 303, fig. 307; E - Dóžecí palác v Benátkách, Itálie, kolem poloviny 14. století; F - náhrobek Ludwiga II. (Železného) von Thuringen († 14. ř́ína 1172, náhrobek okolo 1350), hrad Wartburg, Německo - podle Žákovský-Hošek-Cisár 2012, 103, obr. 11; G - náhrobek hraběte Rudolfa I. von Hohenburg, Sankt Moritz, Torrenburg am Neckar, Bádensko-Württembersko, Německo, po 1336; H - náhrobek Kuna von Falkenstein († 12. května 1343), kostel sv. Galla, Kirchzarten, Bádensko-Württembersko, Německo. Necitovaná vyobrazení pocházejí $\mathrm{z}$ archivu autorů a www.effigiesandbrasses.com.

Abb. 5. Ältere Formen beringter Naseneisen. A - Passionsaltar, Judaskuß, Stift Klosterneuburg, Stiftsgalerie, Österreich, 1335-1340; B - Grab von Friedrich von Truhendingen († 19. Mai 1366), Pfarrkirche St. Kilian in Scheßlitz, Bayern, Deutschland; C -Beckenhaube aus den Sammlungen des Museo Stibbert in Florenz, Italien, um 1350 - nach Klučina 2004, 351; 2011, 838, Abb. 246; D - Grabplatte von Albrecht von Hohenlohe-Möckühl († 1338), Pfarrkirche in Schőnthal an der Jagst, Baden-Württemberg, Deutschland - nach Thordeman 1939, 303, fig. 307; E - Dogenpalais in Venedig, Italien, um Mitte 14. Jhdt; F - Grabplatte von Ludwig II. (der Eiserne) von Thüringen († 14. Oktober 1172, Grabplatte um 1350), Wartburg, Deutschland - nach Žákovský-Hošek-Cisár 2012, 103, Abb. 11; G - Grabmal von Graf Rudolf I. von Hohenburg, Stiftskirche St. Moriz, Rottenburg am Neckar, Baden-Württemberg, Deutschland, nach 1336; H - Grabstein von Kuno von Falkenstein († 12. Mai 1343), Pfarrkirche St. Gallus, Kirchzarten, Baden-Württemberg, Deutschland. Die nicht zitierten Darstellungen stammen aus dem Archiv der Verfasser und von www.effigiesandbrasses.com.

vědném muzeu v Nymburce (dříve v Národním muzeu v Praze), ale popisují ve své obsáhlé studii Wagner-Durdík-Drobná $(1956,60)$. Tato měla mít podle autorů podél okraje tváře a kolem spodní hrany přilby háčky na uchycení závěsu. Přilbu publikoval a i lépe popsal o pár let dříve již B. Novotný (1954), který však uvádí klasické úchytky pro závěs, což dokládají i fotografie (obr. 7:B), a „háčková“ hypotéza tak nemá žádnou oporu ve známých pramenech (přilba je aktuálně v muzejní expozici). Se zvonem přilby byl ovšem objeven i kroužkový závěs, který je však korozními činiteli stmelen do jednoho kusu. Pravděpodobně je jeho součástí i kovový nánosník, který však nebyl dosud rentgenografickým průzkumem zcela prokázán (za informaci děkujeme P. Žákovskému).

Kroužkový závěs mohl být opět podšit měkkou zbrojí k tlumení ran. Soudě dle dochovaných dobových plastik tomu tak ale nebylo vždy (na rozdíl od přilbic). V průběhu 14. století se začal obličejový okraj přilby lemovat ozdobným páskem či aplikacemi nejspíše z ušlechtilých kovů. V podstatě šlo o esteticky hodnotněji provedený prvek pro uchycení kroužkového závěsu (obr. 7:I) 
Kroužkový závěs lemoval přilbu a svému nositeli kryl mj. tváře, krk, bradu a hlavně v pokročilém 14. století byl protažen po obvodu přilby až do oblasti spánků. Na našem území se dochoval kroužkový závěs, který je v současné době vystaven v expozici Státního zámku Hluboká. Je zhotoven z nýtovaných kroužků, přičemž hustota pletiva není ve všech částech stejná. Zajímavostí na něm je neúplný cíp či částečné překrytí obličejové části (Vaverková 1991; 1996). Něco podobného, tzv. aventail či podbradí, bylo používáno u starších kroužkových kompletů, kde bylo napleteno na kapuci. Připnutím podbradí háčkem či tkanicí na druhé straně obličeje u spánku se pak oděnci zakryla až polovina obličeje. Hlubocký závěs je datovaný do druhé poloviny 14. století. Stejně je řešen i závěs uložený v Deutsches Historisches Museum v Berlíně (inv. č. W 3971; obr. 7:H), datovaný zhruba k roku 1360 (Müller-Kunter 1984, 257, obr. 21). V době kolem poloviny 14. století jsou však, dle soudobého výtvarného umění, už typické kroužkové závěsy bez tohoto krytí.

Nevýhodou lehkých přilbic byla především otevřená obličejová část (obr. 5-7). Ta skýtala sice dostatek výhledu a čerstvého vzduchu, ale potřeba chránit obličej vedla už v první polovině století k experimentům s možnostmi jeho ochrany a po roce 1330 tak máme doloženo množství typů a morfologických variant hledí (záměrně neotvíráme problematiku ochrany obličeje v předchozích staletích). Setkáváme se tak s hledími, která byla uchycena na přilbu čepem v místě uprostřed čela, v literatuře označovaná jako klapp (obr 5:C, E; 6:E, F), ale i s hledími, která byla uchycena na dvou čepech umístěných na stranách přilby. Průzory (occularia) pak bývaly v ose hledí umístěny vodorovně nebo lehce od středu šikmo dolů. Ventilační průduchy, umístěné ve spodní části, se pak vyskytovaly v různém rozsahu, od žádných přes jednotlivé díry až po hustě proděravělé plochy (často jen na pravé straně). Stejně tak existovalo množství úchytů hledí na přilbu od pevně fixovaných (přinýtovaných) přes snímatelné až po záchytné odjištovací zámky jištěné vytahovacími závlačkami, někdy jištěné řetízkem či provázkem (obr. 6).

Zhruba od druhé třetiny 14. století až do 70. let (s následným vyzníváním do 15 . století) se stal oblíbenou ochranou obličeje kroužkový náplet (obr. 5), měnící se následně v kovový nánosník (obr. 6), který skýtal při skvělém rozhledu a cirkulaci vzduchu relativně dostatečnou ochranu. Kovové nánosníky byly nejčastěji jednokusové, trojúhelného tvaru, přichycené ve spodní části ke kroužkovému závěsu, v němž v době klidu volně visely. Do boje si ho pak ozbrojenec zavěsil za háček či čep na přilbě v místě uprostřed čela a prrípadně zafixoval jedním z typů zámků, umístěných tamtéž (např̀. obr. 5:C, E; 6). Př́íklady nánosníků tohoto období nacházíme nejčastěji na sepulkrálních plastikách evropského rytířstva oděného do tehdy moderní zbroje, na nichž jsou většinou volně ,zavěšeny“ na kroužkovém závěsu přilby. Patřičný šlechtic je téměř vždy vyobrazen s kbelcem, na kterém leží či ho drží. Šlo tedy o oblíbenou kombinaci lehčí přilby s nánosníkem, přes kterou se v počátku boje či v turnaji nasadil ještě kbelcový helm. $\mathrm{K}$ dnešnímu dni známe takových náhrobků zhruba dvacet a další, vícečetná zobrazení pak z dobových nástěnných a knižních maleb z jižní, západní a stř̌ední Evropy (viz obr. 5-7). Čísla však nepovažujeme za konečná a jistě se podaří v budoucnu dohledat další exempláře (obr. 7).

V horní části nánosníku (či jiného hledí) byl nejčastěji obdélný nebo kř́žzový otvor (více obdélných otvorů, varianty křížů atd.), který se nasadil na háček či výčnělek, navařený či přinýtovaný na středu čelové části přilbice. Zámky zajišt'ující nánosník před uvolněním z háčku či čepu mohly být řešeny různým provedením, která jsou díky neuniformitě středověké výroby (nejen přileb) někdy podobná, leckdy však zcela originální. Obecně se dá ovšem říci, že po zavěšení či natlačení hledí na přilbu bylo toto pak napevno fixováno bud' otočnou destičkou, která spoj zakryla, či tyčinkou, která ji tlakem rozepřela oproti háčku, ale i jejich kombinacemi a variantami (srov. obr. 6). Vyráběly se ovšem i přilby s napevno uchycenou ochranou obličeje (obr. 7:C, E).

Z našeho území pochází snad takový exemplář na deskovém obraze Zmrtvýchvstání Krista od Mistra Třeboňského oltáře, nyní v Národní galerii v Praze, z doby kolem roku 1380 (obr. 7:I; Karel IV. 2006, 502-507). Nositel tohoto šlapu, právě probuzený strážce Božího hrobu s údivem sledující Krista vstávajícího z tumby, má vzhưru odklopené hledí tvaru „rybí kosti“, tedy svislé železné tyčinky, ze které po obou stranách v pěti řadách vybíhají od shora dolů se zužující tyčinky horizontální. 

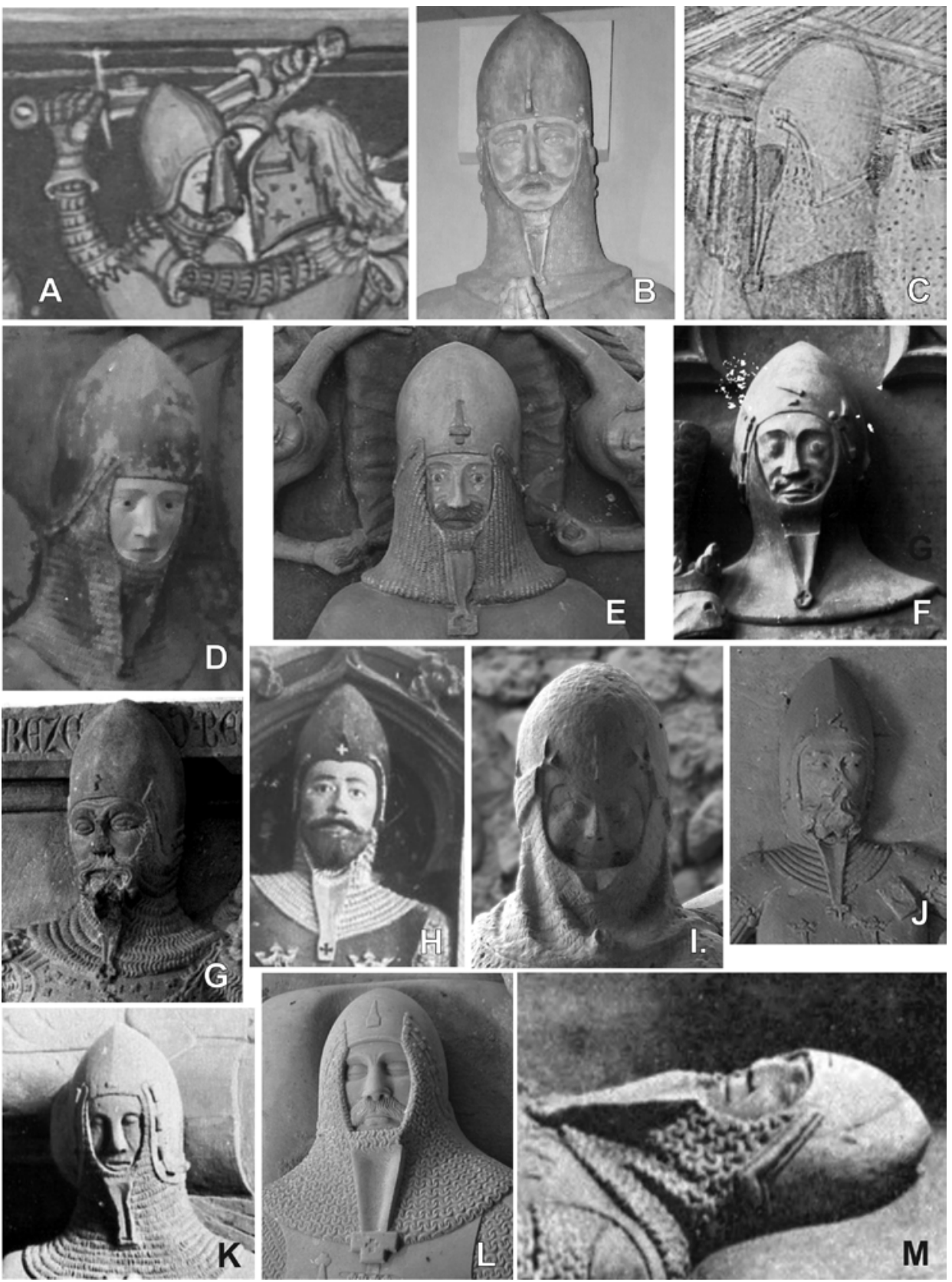

Obr. 6. Vyspělejší (plechová) varianta nánosníku. A - Rudolf von Ems, Weltchronik, fol. 85v, Bayerische StaatsBibliothek, Cod. germ. 5, Německo, kolem 1370 (v rukopise je vícečetné zobrazení nánosníkủ); B - náhrobek Bertholda V. von Zähringen († 18. února 1218, náhrobek okolo 1354), katedrála ve Freiburgu, Bádensko-Württembersko, Německo; $C$ - Roman de Giron le Courtois, fol. 26r, Bibliothèque nationale de France, Département des manuscrits, NAF 5243, Francie, 1301-1400 (2. polovina 14. století); D - náhrobek Ludwiga von Öttingen, Kirchheim am Reis, Bádensko-Württembersko, Německo, kolem 1360; E - náhrobek Ulricha V. Landschada von Steinach, kostel v Neckerstainach, Hesensko, Německo, 1369-1371; F - náhrobek Günthera XXI. von Schwarzburg († 14. června 1349), katedrála sv. Bartoloměje, Frankfurt nad Mohanem, Německo, po 1349; G - náhrobek Rezza von Bachlingen, kostel sv. Jana v Bachlingen, Německo, 1350-1360; H - náhrobek Albrechta (Alberta) von Barby († 1358), kostel sv. Jana v Barby, Sasko, Německo, 1358; I - náhrobek Cangrande I. Della 
Scala († 22. července 1329), Museo di Castelvecchio, Verona, Itálie, po 1329; J - náhrobek Johanna von Falkenstein z Arnsburgu, klášter Arnsburg, kapitulní síň, Hesensko, Německo, 1365; K-náhrobek Burkharda von Sturmfeder († 1364), kostel (dříve sv. Jakuba Staršího) v Oppenweiler, Bádensko-Württembersko, Německo, po 1364; L - náhrobek Galeotta Malaspiny († 15. března 1367), kostel sv. Remigia, Fosdinovo, Toskánsko, Itálie, 1367; M - náhrobek Manna Donati, bazilika sv. Antonína Paduánského, Padua, Veneto, Itálie, 1. polovina 70. let 14. století. Necitovaná vyobrazení pocházejí z archivu autorů a www.effigiesandbrasses.com.

Abb. 6. Entwickeltere Naseneisenvarianten (aus Blech). A - Rudolf von Ems, Weltchronik, fol. 85v, Bayerische Staatsbibliothek, Cod. germ. 5, Deutschland, um 1370 (die Handschrift enthält zahlreiche Abbildungen von Naseneisen); B - Grabmal von Berthold V. von Zähringen († 18. Februar 1218, Grabmal um 1354), Freiburger Münster, Baden-Württemberg, Deutschland; C - Roman de Giron le Courtois, fol. 26r, Bibliothèque nationale de France, Département des manuscrits, NAF 5243, Frankreich, 1301-1400 (2. Hälfte 14. Jhdt.); D - Grabstein Ludwig von Öttingen, Kirchheim am Ries, Baden-Württemberg, Deutschland, um 1360; E - Tumbenplatte von Ulrich V. Landschad von Steinach, Kiche in Neckerstainach, Hessen, Deutschland, 1369-1371; F - Grabstein von Günther XXI. von Schwarzburg († 14. Juni 1349), Kaiserdom St. Bartholomäus, Frankfurt am Main, Deutschland, nach 1349; G - Grabdenkmal von Rezzo von Bächlingen, Johanneskirche in Bächlingen, Deutschland, 1350-1360; H - Grabplatte von Albrecht (Albert) von Barby († 1358), Johanniskirche in Barby, Sachsen, Deutschland, 1358; I - Grabdenkmal von Cangrande I. Della Scala († 22. Juli 1329), Museo di Castelvecchio, Verona, Italien, nach 1329; J - Grabplatte von Johann von Falkenstein aus Arnsburg, Kloster Arnsburg, Kapitelsaal, Hessen, Deutschland, 1365; K-Grabplatte von Burkhard von Sturmfeder († 1364), Pfarrkirche (ehemals Sankt Jakobus der Ältere) in Oppenweiler, Baden-Württemberg, Deutschland, nach 1364; L - Grabmal von Galeotto Malaspina († 15. März 1367), Pfarrkirche St. Remigius, Fosdinovo, Toskana, Italien, 1367; M - Grabmal von Manno Donati, Basilika des Heiligen Antonius von Padua, Padua, Venetien, Italien, 1. Hälfte siebziger Jahre des 14. Jhdts. Nicht zitierte Abbildungen stammen aus dem Archiv der Verfasser und von www.effigiesandbrasses.com.

Zkusíme-li podle analogií dohledat, jak byl na přilbě jištěn ronovecký nánosník, ukazuje se, že by mohl být tento exemplář původně jištěn před ztrátou pomocí „rozepřené tyčinky“ či „kyvadlového zámku“ umístěného na přilbě. $V$ prvním prípadě by byl nánosník nasazen/zavěšen na křižový výčnělek na přilbě a zajišsěn proti vypadnutí tyčinkou tlačící spodní plochou vůči hornímu okraji hledí (např. náhrobek Günthera XXI. von Schwarzburg, obr. 6:F). V druhém př́ípadě by byl po nasazení zakryt kyvadlovým zámkem (srov. originál šlapu v Coburgu, inv. č. A. I.1 Scalini 1996, 57, nebo náhrobky Ulricha V. Landschada von Steinach - obr. 6:E, či Galeotta Malaspiny v kostele sv. Remigia v Itálii - obr. 6:L). Tato varianta se nám zdá pravděpodobnější, nebot' ronovecké hledí je unikátní ve své konstrukci. Tento nánosník nebyl pravděpodobně uchycen pod bradou ke kroužkovému pletivu, jak to bylo běžné, nýbrž jen na čepu přilby. Mimo bojovou situaci mohl být odklopen směrem vzhůru, v této poloze zůstal zafixovaný díky pantu (styčné plochy byly vykovány nepravidelně a odklopením vzhůru se rozepřely a hledí v dané poloze zajistily - pant je $v$ dobových pramenech nejlépe patrný u vojáků sv. Abondia v Como, obr. 7:E, srov. s obr. 4). V př́ípadě boje byl sklopen dolů a byl zafixován výčnělkem horní části, která se tentokráte rozepřela oproti vrchní hraně spodní části nánosníku. Potřeboval-li nositel použít jiný typ hledí, nánosník po povolení zámku prostě z přilby sejmul. Tímto jednoduchým a originálním řešením se řadí ronovecký nánosník $\mathrm{k}$ naprostým unikátům, a dosud $\mathrm{k}$ němu neznáme žádnou analogii z archeologických sbírek. Svým způsobem jde o zatím nejdůmyslněǰši známý exemplář této varianty hledí.

Jak je patrné z předchozího, ronovecký nánosník lze datovat pouze rámcově, resp. relativně přesně je datovatelný co do doby jeho vzniku. Hůře už můžeme posoudit délku, případně prostř̌edí jeho užívání. $\mathrm{V}$ době pravděpodobné životnosti nánosníku byl hrad v držení pánů z Lipé a následně se stal lénem Ješka z Ronovce a jeho rodiny (od roku 1362). Ješek sám proslul zejména svým intimním životem a (v důsledku toho) problémy s financemi (srov. Rous 2013). Jeho dva synové, snad po jeho smrti po roce 1392, aktivně působili v bojových družinách zejména moravských drobných válek, kde si nejspiśe vysloužili ironické (?) př́ízvisko Andělé. Po uklidnění situace v království se oba Ronovci nechali najmout pro válku v Polsku (1409). Jan na straně řádu německých rytîrů a Petr na straně polsko-litevské unie (Štěpán 1997, 154-156; přehledně Rous 2013; Belcredi 2012, 32). Neznáme sice přesně osudy hradu na počátku 15. století, ale předpokládáme, že byl opuštěn v souvislosti se spory po smrti Jindřicha z Lipé po roce 1406. Můžeme snad spekulovat, že to vedlo i ke vstupu Ronovců do vzdálené polské války. Právě bojová činnost bratrů Andělů by pro nás mohla představovat zajímavý moment $\mathrm{v}$ př́ípadné vazbě nálezu na bojové družiny a jejich výzbroj. Depozici nánosníku v prostoru hradu bychom také mohli spojovat např́ḱlad s neplánovaným postupným zánikem stavby v návaznosti na zmíněné dědické spory. Jak bylo uvedeno výše, v bohatých vojenských dějích, které okolí v 15. století postihly 

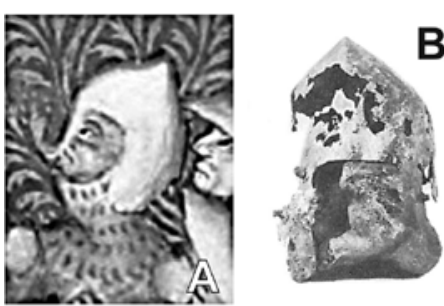

B
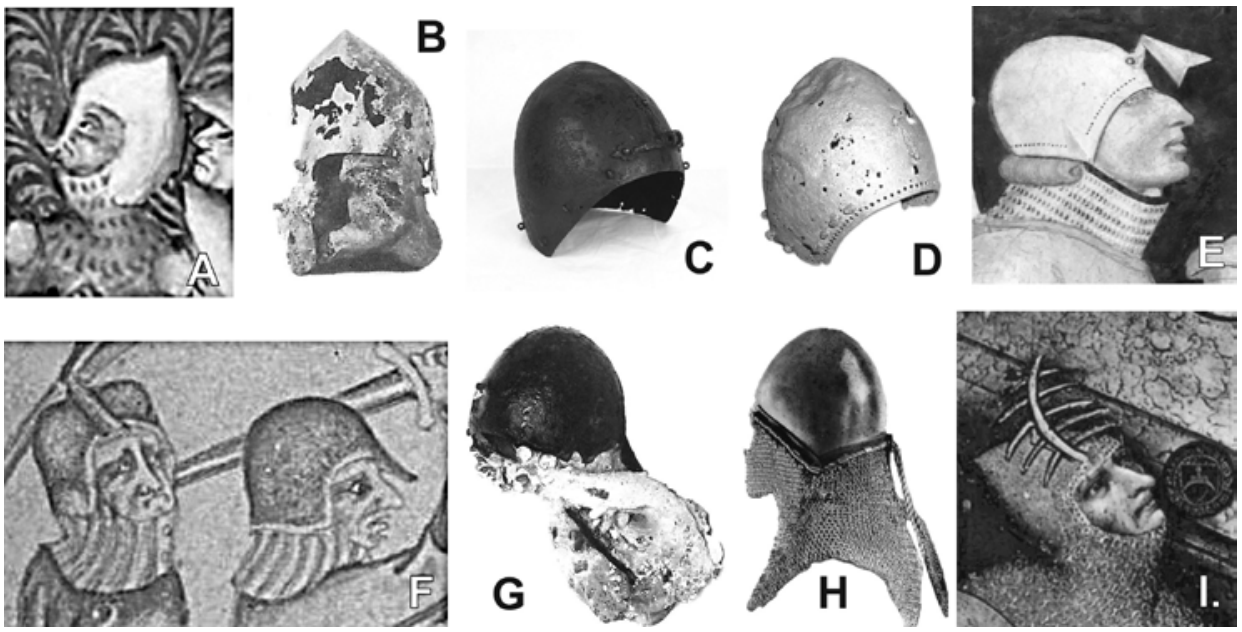

Obr. 7. Nánosníky napevno fixované, vzhůru odklopné a vybrané originály přileb. A - Guillaume de Machaut, Poésies, fol. 73v, Bibliothèque nationale de France, Département des manuscrits, Français 1586, Francie 1350-1355; B - přilba typu šlap (Beckenhaube) z Kostomlat u Nymburka, Vlastivědné muzeum Nymburk, střední Evropa (Čechy), 2. polovina 14. století - podle Novotný 1954, 153, obr. 1-2; C - přilba typu šlap z Boves, Armeria Reale Torino, Itálie, 3. třetina 14. století - podle Angeluci 1890; Klučina 2004, 371; zdroj http://www.armeriareale.beniculturali.it; D - přilba typu šlap z hradu Lopata, Západočeské muzeum v Plzni, inv. č. HA 3841, střední Evropa (Čechy), ca 1340-1370 - podle Frýda 1996, 534; Novobilský 2008, 87, obr. 96; Žákovský 2011, 873, obr. 320; E - Bazilika sv. Abbondia v Como - nástěnné malby, Itálie, kolem poloviny 14. století (vícečetná zobrazení); F - Holkhamská bible, fol. 40r, British Library, MS 47682, Anglie, 1327-1335, zdroj http://www.bl.uk/manuscripts/FullDisplay.aspx?ref=Add_MS_47682; G - přilba typu šlap s kroužkovým závěsem a nánosníkem, Armeria della Rocca, Mondavio, 14. století - podle Mauro 1989, 20, č. kat. 7; Žákovský 2011, 845, obr. 257; H - přilba typu šlap s kroužkovým závěsem uložená v Deutsches Historisches Museum, inv. č. W 3971, Německo, okolo 1360 - podle Müller-Kunter 1984, 257, obr. 21; I - Mistr Třeboňského oltáře, Zmrtvýchvstání Krista, Národní galerie v Praze, inv. č. O 477, Čechy po roce 1380 - podle Karel IV. 2006, 466-467. Necitovaná vyobrazení pocházejí z archivu autorů a www.effigiesandbrasses.com.

Abb. 7. Fest fixierte, oben aufklappbare Naseneisen und ausgewählte Originalhelme. A - Guillaume de Machaut, Poésies, fol. 73v, Bibliothèque nationale de France, Département des manuscrits, Français 1586, Frankreich 1350-1355; B -Beckenhaube aus Kostomlaty bei Nymburk, Heimatmuseum Nymburk, Mitteleuropa (Böhmen), 2. Hälfte 14. Jhdt.- nach Novotný 1954, 153, Abb. 1-2; C - Beckenhaube aus Boves, Armeria Reale Torino, Italien, 3. Drittel 14. Jhdt.- nach Angeluci 1890; Klučina 2004, 371; Quelle http://www.armeriareale.beniculturali.it; D - Beckenhaube von Burg Lopata, Westböhmisches Museum in Pilsen, Inv.-Nr. HA 3841, Mitteleuropa (Böhmen), ca. 1340-1370 - nach Frýda 1996, 534; Novobilský 2008, 87, Abb. 96; Žákovský 2011, 873, Abb. 320; E - Basilika Sant'Abbondio in Como - Wandmalerei, Italien, um Mitte 14. Jhdt. (mehrfache Darstellungen); F - Holkham Bibel, fol. 40r, British Library, MS 47682, England, 1327-1335, Quelle http://www.bl.uk/manuscripts/FullDisplay.aspx?ref=Add_MS_47682; G - Beckenhaube mit Kettengeflecht und Naseneisen, Armeria della Rocca, Mondavio, 14. Jhdt.- nach Mauro 1989, 20, Kat. Nr. 7; Žákovský 2011, 845, Abb. 257; H - im Deutschen Historischen Museum aufbewahrte Beckenhaube mit Kettengeflecht, Inv.-Nr. W 3971, Deutschland, um 1360 - nach Müller-Kunter 1984, 257, Abb. 21; I - Meister des Třeboner Altars, Auferstehung Christi, Nationalgalerie in Prag, Inv.-Nr. O 477, Böhmen nach 1380 - nach Karel IV. 2006, 466-467. Nicht zitierte Abbildungen stammen aus dem Archiv der Verfasser und von www.effigiesandbrasses.com.

(obsazení Chotěboře husity, bitva u Německého Brodu, Žižkovo tažení k Přibyslavi atd.), se hrad neobjevuje (alespoň nám to není známo). Podobně jako nedaleký Sokolov zaniklý nejspíše akcí královského vojska roku 1407 jako sídlo loupeživých rytířu Jana z Chotělic a Pavla Hubenky ze Zišova (Durdík 1999, 510; Hájek-Rous 2013). Nabízí se otázka, zda pobyt královského vojska nemohl mít vliv také na devět kilometrů vzdálený Ronovec, nacházející se možná ještě v rukou bojovných bratř́i Andělů.

Ideovým spojením mezi lokalitami s přítomností bojových družin je také existence předhradí Ronovce s konstrukcí vnitřního valu, jakou nalezneme také na nedalekém Sokolově. V současnosti byly publikovány úvahy o funkci takových předhradí v př́ípadě Sionu (Koscelník-Kypta-Savková 2013), středočeských hradů a patrně také Ronova nad Sázavou, který byl majetkem pravděpodobného majitele bojové družiny Čeňka z Ronova a Přibyslavi (Hoffmann 1987, 81; Sýkora 2012; konzultace s M. Sýkorou). Díky nejasné nálezové situaci nejsme tedy schopni nánosník absolutně datovat, ovšem v porovnání s výše uvedenými prameny lze za dobu jeho vzniku určit druhou polovinu 14. století, snad přímo jeho třetí čtvrtinu. Vzhledem k ostat- 
ním nálezům získaným na hradě (Čapek 1999; Knápek 2013; 2014), geologickým podmínkám a kompaktnosti hradního jádra bychom předpokládali spíše pozdější uložení. Počátek archeologizace tedy mohl být zahájen až v průběhu prvních decennií 15 . století.

Co se týče rozšiřrení přileb v rámci dobové výzbroje, již v době Karla IV. víme o stovkách kusů v městských zbrojnicích. K roku 1362 je totiž v Karlově (IV.) revizi vojenského vybavení zmiňováno soudcem a radním z Vysokého Mýta mj. „,...) ducentas triginta septem barbutas cum appendiciis (...)“, tedy 237 barbut s přívěsky (CIB II/3, 103-104). „Přívěskem“ je v tomto př́ípadě myšlen snad kroužkový závěs, může ovšem jít i o jiné prvky přileb jako hledí apod. Wagner-Durdík-Drobná $(1956,60)$ výraz barbuta doslovně překládají jako „bradatici“ a dávají ji podle dalších historických zmínek z Loun z konce 14. století do paralely ke cassis, tedy „lebce“. Pro rok 1395 známe i výbavu chebské hotovosti, v níž je opět většina bojovníků přilbou vybavena (Durdík 1968).

Podíváme-li se na tematicky výrazně hojnější písemné prameny z Polska, pak můžeme jmenovat alespoň k roku 1404 zmínku o lehnických měšt’anech, kteří měli ,, haube myt eyne gehenge“, tedy „lebku“s kroužkovým závěsem, v počtu 28 ks, a dalších 206 železných klobouků.

V Javoře (Jawor) měli roku 1385 na radnici uskladněno, ,seben ysenhute pictos und eynen breyten ungemolten ysenhut", tedy železné klobouky. Roku 1413 zde pak byly uskladněny čtyři lebky a jedenáct kapalínů (železných klobouků) a dokonce i „uj hundiskappin und eyn gehenge“. Šlo tedy o tehdy nejmodernější variantu šlapu s kroužkovým závěsem a hledím tvaru „psího nosu“. Na rozšíření této přilbice odkazuje další písemná zmínka z roku 1389: „,...) die hundskugeln fuhrten ritter und knecht, burger und reisige leut (...)“(Heś 2007, 25-26, 29, 34).

Zajímavá je i zmínka o krakovských měšt’anech, kterým nařizoval branný seznam cechů z roku 1427 shromáždit 169 přileb, přičemž z toho mělo být 145 kapalínů (Nadolski ed. 1994, 226).

Ronovecký nánosník se díky svému jednoduchému a funkčnímu zpracování, ale i díky svým vlastnostem spojujícím prvky ochrany, dobrého výhledu a cirkulace vzduchu mohl uplatnit jak na přilbě řadových vojáků, tak i ve výzbroji urozeného majitele hradu, soudě dle dobových obrazových a sochařských analogií a písemných pramenů (srov. vyobrazení ve Světové kronice z doby kolem roku 1370 - BSB, 176, 243, 258; př́ípadně zde ve výřezu obr. 6:A). Pro představu o rozsahu hradní posádky máme jedinečný doklad v závěti Smila ze Šternberka a Holštejna z roku 1398. Tento popisuje celkem 36 svých lidí žijících na hradě, z nichž 26 bylo bojovníků a mělo k dispozici „(...) helmy, pláty, pušky (...)“(Belcredi 2012, 16).

Přes ne zcela jasné nálezové okolnosti patři ronovecký nánosník mezi unikátní militaria dokumentující různorodost středověké vojenské praxe. Jak je patrné z textu, patří k druhu památek, které se ze své povahy a použití zachovaly spíše výjimečně. Soudobé medievistické a archeologické bádání přináší nové informace týkající se různorodosti a nelineárního vývoje zbraní a zbroje vrcholného a pozdního středověku. Dochází také ke zpřesňování datací již dříve známých artefaktů, a obraz dobové reality tak nabývá stále plastičtější podoby. Ronovecký nánosník je zajímavý nejen po stránce technické, ale také pravděpodobným spojením s činností bratrů Ronovců po stránce výbavy bojových družin přelomu 14. a 15. století. Aktivita těchto skupin velmi ovlivnila život na česko-moravském pomezí i v nedalekém okolí (např. Přibyslav, Ronov nebo Skály, viz např. Hoffmann 1987; Belcredi 2012, 18-38; Andělé jsou zmiňováni pak na s. 18, 29 a hlavně 32). Poznání tohoto fenoménu však zatím zdaleka není úplné a o denní realitě příslušníků zmíněných bojových družin to platí téměř beze zbytku.

\section{Prameny a literatura}

ANGELUCCI, A., 1890: Catalogo della Armeria Reale. Torino. BELCREDI, L., 2012: Hrad Skály aneb o prstenu paní Elišky. Historie a archeologický výzkum hradu. Brno. BLAIR, C., 1958: European Armour, circa 1066 to circa 1700. New York.

BOEHEIM, W., 1890: Handbuch der Waffenkunde. Leipzig.

CIB: Codex juris Bohemici, tomi II., pars 3 (Jireček, E., ed.). Pragae 1189. 
ČAPEK, J., 2009: Za temnou historií zapomenutého hradu Ronovce. Rukopis ulož. v Muzeu Vysočiny v Havlíčkově Brodě.

DURDÍK, J., 1968: Vojenská hotovost chebského venkova v r. 1395, Historie a vojenství, č. 4, 561-583.

- 1999: Ilustrovaná encyklopedie českých hradů. Praha.

FRÝDA, M., 1996: Militaria. In: Gotika v západních Čechách (1230-1530) II. (Fajt, J., ed.), 531-535. Praha.

FUNCKEN, L.-FUNCKEN, F., 2001: Historische Waffen und Rüstungen. Ritter und Landsknechte vom 8. bis 16. Jahrhundert. München.

GESSLER, E. A., 1923: Die Spangenharnische von Küssnach, Zeitschrift für historische Waffen und Kostümkunde 10, NF 1, 211-215.

GLINIANOWICZ, M., 2010: Zasłona typu „psi pysk“ ze zbiorów Muzeum wojska polskiego w Warszawie, Acta Militaria Mediaevalia VI, 193-210.

- 2005: Stan badań nad uzbrojeniem późnośredniowiecznym w Małopolsce, Acta Militaria Mediaevalia I, $143-164$.

GŁOSEK, M., 2007: Przyczynek do genezy hełmów typu przyłbica. In: Od pradziejów po współczesnośc. Archeologiczne wędrówki (Głosek, M.-Maik, J., edd.), 14-16. Łódź.

GOŠ, V., 1976: Soubor železných předmětů a zbroje z hradu Rychleb ve Slezsku, VVM 29, 293-300.

GRABARCZYK, T.-ŁAWRYNOWICZ, O., 2006: Zbraně a zbroj v miniaturách pařížského zlomku latinského překladu Kroniky tzv. Dalimila - Waffen und Rüstungen auf den Miniaturen des Pariser Fragments der lateinischen Übersetzung der sog. Dalimil Chronik, CB 10, 257-280.

HÁJEK, J.-ROUS, P., 2014: Hrad Sokolov u Chotěboře, AVV 4/2013, 19-38.

HEŚ, R., 2007: Uzbrojenie rycerskie na Śląsku w XIV wieku. Wrocław - Racibórz.

HERMANN, F. a kol., 2007: Hermann, F.-Hermann, W.-Rief, T.-Wagner, E. L., Hermann Historica OHG, München. 52. Auktion. Alte Waffen - Antiken - Jagdliches - Varia. München.

HOFFMANN, F., 1987: Bojové družiny před husitskou revolucí ve východních Čechách, ČČH 35, 75-103.

KAREL IV., 2006: Karel IV. Císař z Boží milosti. Kultura a umění za vlády Lucemburků 1310-1437 (Fajt, J., ed.). Praha.

KLUČINA, P., 2004: Zbroj a zbraně. Evropa 6.-17. století. Praha - Litomyšl.

- 2011: Vojenské aspekty doby Jana Lucemburského. In: Král, který létal. Moravsko-slezské pomezí v kontextu středoevropského prostoru doby Jana Lucemburského (Majer, D., ed.), 793-840. Ostrava.

KNÁPEK, A., 2012: Ronovec, několik poznámek k podobě a stavu hradu. In: Havlíčkobrodsko 26, $187-195$. Havlíčkův Brod.

- 2014: Ronovec. 55 let průzkumů hradu. In: Vyhlídky na věčnost, v tisku.

- 2013: Ronovecké unikáty. In: Hrad Ronovec a Dolní Krupá. Sborník věnovaný památce Josefa Čapka (1909-1988) (Knápek, A., ed.) [e-kniha, online], 13-23. Havlíčkův Brod.

KOSCELNÍK, P.-KYPTA, J.-SAVKOVÁ, J., 2013: Dobývání hradu Siónu roku 1437. Povrchový průzkum palebných postavení obléhatelů - The capture of Sión Castle in 1437. A surface survey of the besieging army's firing positions, AR LXV, 574-598.

KRONIKA DOLNÍ KRUPÉ: Kronika Dolní Krupé. Rukopis z let 1947-? (Čapek, J., ed.), ulož. v muzeu v Dolní Krupé, kopie v Muzeu Vysočiny v Havlíčkově Brodě.

LE DUC, V., 2008: Encyclopedie medievale. Tome II. Architecture et mobilier. Tours.

MAURO, M., 1989: Armeria della Rocca. Mostra di armi antiche. Mondavio.

MOTYKOVÁ, K., 2001: Středověká přilba z Nymburka, ČSPS CIX, 1-10.

MÜLlER, H.-KUNTER, F., 1984: Europäische Helme aus der Sammlung des Museums für Deutsche Geschichte. Berlin.

NADOLSKI, A., ed., 1994: Polska technika wojskowa do 1500 roku. Z dzejów nauki i techniky I. Warszawa.

NICKEL, H., 1974: Ullstein Waffenbuch. Eine kulturhistorische Waffenkunde mit Markenverzeichnis. Berlin - Frankfurt am Main - Wien.

NOVOBILSKÝ, M., 2008: Obléhání hradu Lopaty. Rekonstrukce obléhání hradu z roku 1432-1433. Plzeň.

NOVOTNÝ, B., 1954: Železná přilba z Kostomlat, ČNM CXXIII, 153-156.

NOWAKOWSKI, A., 1989: Średniowieczny hełm z Olsztyna, Rocznik Olsztyński XVI, 147-154.

- 1994: Arms and Armour in the Medieval Teutonic Order's in Prussia. Łódź.

- 1997: Jeszcze o „psich pyskach“. In: Archeologia i starożytnicy. Studia dedykowane profesorowi Andrzejowi Abramowiczowi w 70. rocznicę urodzin (Głosek, M., ed.), 229-236. Łódź.

OAKESHOTT, E., 1991: Records of the medieval sword. Woodbridge.

PIERZAK, J., 2004: Hełmy garnczkowe na ziemiach Polskich na tle Zachodnioeuropejskim. Rukopis doktorské práce, Uniwersytet Jagielloński w Krakowie, Institut archeologii, vedoucí práce prof. dr. hab. Piotr Kaczanowski.

PǨIHODA, R., 1929: Der Reichensteiner Spangenharnisch, Zeitschrift für historische Waffen und Kostümkunde 12, NF 3, 112. 
ROUS, P., 2013: K otázce padělání mincí na hradě Ronovec. In: Hrad Ronovec a Dolní Krupá. Sborník věnovaný památce Josefa Čapka (1909-1988) (Knápek, A., ed.) [e-kniha, online], 48-58. Havlíčkův Brod.

- 2014: Anděl z Krupé. In: Havlíčkobrodsko 28, 273-279. Havlíčkův Brod.

SCALINI, M., 1996: The Armory of the Castle of Chruburg. Udine.

SOMMER, T., 2013: Smil z Lichtenburka a hrad Ronovec (Sommerburg). In: Hrad Ronovec a Dolní Krupá. Sborník věnovaný památce Josefa Čapka (1909-1988) (Knápek, A., ed.) [e-kniha, online], 24-33. Havlíčkův Brod.

STARÝ, M., 1999: Zemský písař Štěpán z Tetína, jeho původ a potomstvo, Genealogické a heraldické listy $3-4,27-37$.

- 2012: Kalich, Panna a Litýš - tři hrady doby husitské na Třebušínsku, CB 13, 9-23.

THORDEMAN, B., 1939: Armour from the battle of Wisby 1361, Vol. I, II. Uppsala.

VAVERKOVÁ, Z., 1991: Kroužkový závěs k basinetu ze zámku Hluboká - Kettenschutz am Helm (cassis basinet) aus dem Schloss Hluboká, AH 16, 379-384.

- 1996: Historické zbraně 15.-19. století. České Budějovice.

VÍCH, D., 2009: Orlické muzeum v Chocni. Katalog archeologické sbírky. Zprávy České archeologické společnosti - Supplément 74. Praha.

WAGNER, E.-DURDÍK, J.-DROBNÁ, Z., 1956: Kroj, zbroj a zbraně doby předhusitské a husitské. Praha. WILIAMS, A.-EDGE, D., 2004: Great helms and their development into helmets, Gladius XXIV, $123-134$.

ŽÁKOVSKÝ, P., 2009: Hromadný nález nejstarších platnéřských prací z území Moravy (?). Příspěvek k poznání tzv. kombinovaných zbrojí - Ein Sammelfund der ältesten Plattnerarbeiten auf mährischem Gebiet? Ein Beitrag zum Verständnis sogenannter kombinierter Rüstungen, AH 34, 409-444.

-2011: Zbraně a zbroj z první poloviny 14. století ve stř̌ední Evropě. Katalog militarií. In: Král, který létal. Moravsko-slezské pomezí v kontextu středoevropského prostoru doby Jana Lucemburského (Majer, D., ed.), 841-879. Ostrava.

ŽÁKOVSKÝ, P.-HOŠEK, J.-CISÁR, V., 2012: A Unique finding of a great helm from the Dalečín castle in Moravia, Acta Militaria Mediaevalia VIII, 91-125.

\section{Internetové zdroje}

ARMERIA REALE, Torino, inv. č. PP1159, http://www.artito.arti.beniculturali.it:81/Armeria\%20Reale/5PERCORSO/Didascalia.asp?ID=1928, cit. 27. 11. 2015.

BSB-Hss Cgm 5, Weltchronik in Versen - Mischhandschrift aus Christ-herre-Chronik, Rudolf (von Ems) Jansen Enikel, okolo 1370, http://daten.digitale-sammlungen.de/ db/0007/bsb00079954/images/.

DEUTSCHES HISTORISCHES MUSEUM, Berlin, inv. č. W 3971, http://www.dhm.de/datenbank/dhm. php?seite=5 \& fld_0=AK204878, cit. 27. 11. 2015.

EFFIGIES AND BRĀSSES, www.effigiesandbrasses.com.

\section{Zusammenfassung}

\section{Ein einzigartiger Bestandteil einer Rüstung von Burg Ronovec (Bezirk Havlíčkův Brod)}

Im Jahr 1958 wurde auf Burg Ronovec (ansonsten auch Sommerburg, gegründet nach Mitte des 13. Jahrhunderts) ein fast gänzlich erhaltenes Naseneisen entdeckt, das als einfaches Klappvisier diente. Die Fundumstände konnten, besonders was die Stratigraphie betrifft, bislang nur mühselig rekonstruiert werden (,an der Brunnenwestseite dicht an der Wehrmauer").

Das Naseneisen hat eine annähernd dreieckige Form, von seiner Grundfläche aus verjüngt es sich, wobei es ungefähr in halber Höhe auf beiden Seiten segmentartig zugeschnitten wurde. Es besteht aus drei Eisenteilen. Der größte, unvollständige untere Teil hat eine erhaltene Länge von $11 \mathrm{~cm}$. Es handelt sich um eine konvex geknickte Spatenform mit Mittelgrat, der im oberen Teil ausläuft. Diese Wölbung weist gegenüber dem Rand einen Höhenunterschied von 2,2 cm auf, wodurch eine Stärkung der Materialfestigkeit erreicht wird, um dem eventuellen Einsatz einer Waffe besser entgegenzuwirken, gleichzeitig spiegelt die Form auch die Anatomie des verdeckten Gesichtes wider. Die erhalten gebliebene Materialstärke bewegt sich von ca. 1,5 mm im unteren Teil bis zu $5 \mathrm{~mm}$ im oberen Teil (wobei der Korrosionsfaktor berücksichtigt werden muss). Dieser 
wird von zwei breiter werdenden, umgeschlagenen und geschweißten (?) Streifen bzw. Stäben abgeschlossen, die dadurch eine Öffnung bilden, durch welche ein Rundeisen gesteckt wird. Das so entstandene Scharnier dient zur Befestigung des beweglichen oberen Teils des Naseneisens. Dieses besteht aus einem 4-5 mm starken und $5 \mathrm{~cm}$ hohen Teilstück, das in die Form eines langgestreckten Sechsecks geschmiedet wurde, dessen Unterseite eine längliche Nase bildet. In der Mitte wurde eine kreuzförmige Öffnung ausgestanzt. Gegenwärtig ist das Scharnier eingerostet und beide Hauptteile bilden zusammen fast einen rechten Winkel. Das Naseneisen ist demnach in „offenem“ Zustand fixiert.

Der Naseneisentyp des Visiers wurde ungefähr ab dem zweiten Viertel bis Ende des 14. Jahrhunderts getragen, wobei erwartet werden kann, dass noch in den anschließenden Jahrzehnten des darauffolgenden Jahrhunderts Nachklänge von ihm auftraten. Die angegebene Spanne entspricht vor allem dem Zeitraum, als die Burg sich im Besitz des absonderlichen Ješek von Zlíchov (Tetín) und dessen Söhnen befand, die später als Mitglieder von Räuberbanden und Kampfgefolgschaften wahrscheinlich ironisch Engel genannt wurden. Sie nahmen u.a. an kleinen einheimischen Kriegszügen sowie ausländischen Militäroperationen teil.

$\mathrm{Ob}$ dieser Bestandteil einer Rüstung ursprünglich dem adeligen Besitzer der Burg bzw. jemandem aus dessen Gefolgschaft oder einem ordentlichen Soldaten gehörte, lässt sich nicht bestimmen, da dieser Visiertyp in allen sozialen Schichten des Militärs beliebt war, wie dies sowohl in schriftlichen, als auch in ikonographischen Quellen belegt wird. Jedenfalls handelt es sich um eine spezielle Form dieser Art von Militaria, die in dem bisher veröffentlichten Material bislang keine Analogie besitzt.

Mgr. Aleš Knápek, Muzeum Vysočiny Havlíčkův Brod, Havličkovo náměstí 19, 58001 Havlíčkův Brod, Česká republika, knapek@muzeumhb.cz

Mgr. Pavel Macků, Národní památkový ústav, ú. o. p. v Telči, Hradecká 6, 58856 Telč, Česká republika, macku.pavel@npu.cz 